\title{
The Protective Effects of an Adsorbent against Oxidative Stress in Quails Fed Aflatoxin-Contaminated Diet
}

\author{
Marcos José Migliorini' ${ }^{1}$ Aleksandro Schafer Da Silva ${ }^{1,2}$, Janio Morais Santurio ${ }^{3}$, Nathieli Bianchi Bottari', \\ Roger Rocha Gebert', João Henrique Reis', Andreia Volpato', Vera Maria Morsch', \\ Matheus Dellaméa Baldissera ${ }^{3}$, Lenita Moura Stefani' \& Marcel Manete Boiago'1
}

\begin{abstract}
Background: Contamination of crops with aflatoxin is considered a serious global threat to food safety, since potent carcinogenic, teratogenic, mutagenic and immunosuppressive effects of aflatoxins are well recognized. Recently, the use of adsorbents has been linked with protective effects against oxidative stress in several diseases. Thus, the aim of this study was to assess the occurrence of oxidative stress in quails (Coturnix coturnix) fed with aflatoxin-contaminated diet, as well as the protective effect of an adsorbent.
\end{abstract}

Materials, Methods \& Results: Twenty-eight quails were divided into four groups ( $\mathrm{n}=7$ ): diet without additives (control; the group A), diet and adsorbent containing aluminosilicates (the group B), aflatoxin-contaminated diet (200 ppb) (the group C), and aflatoxin-contaminated diet (200 ppb) and adsorbent containing aluminosilicates (the group D). The composition of the adsorbent containing aluminosilicates was $0.3 \%$ based on yeast cell wall, silymarin, and bentonite. The animals received feed and water ad libitum during 20 days. At the end of the experimental period, total blood was collected by cardiac puncture in tubes without anticoagulant to obtain serum (centrifuged at $3500 \mathrm{~g}$ during $10 \mathrm{~min}$ ) for later determination of biochemical parameters. The liver was placed in a solution of Tris- $\mathrm{HCl} 10 \mathrm{mM}, \mathrm{pH}$ 7.4 for TBARS (Thiobarbituric acid reactive substances), ROS (Reactive oxygen species), SOD (Superoxide dismutase) and CAT (Catalase) analysis. The hepatic tissue was gently homogenized in a glass potter in specific buffer, homogenated, and centrifuged at $10.000 \mathrm{~g}$ at $4^{\circ} \mathrm{C}$ for $10 \mathrm{~min}$ to yield a supernatant (S1) used for analyses. Homogenate aliquots were stored at $-80^{\circ} \mathrm{C}$ until utilization. Fragments of liver and intestine $(5 \mathrm{~cm})$ were collected for histopathological analyses. Between days 15 to 20 of the experiment, group $\mathrm{C}$ quails showed clinical signs, such as apathy, creepy feathers and reduced feed intake. At day 20 of experiment, macroscopically, the liver of quails belonging to the group $\mathrm{C}$ showed greenish yellow color differently from the other groups. Microscopically, no alterations were observed in the liver of animals in groups A and B. Severe diffuse microvacuolar degeneration (hydropic) of hepatocytes and small foci of necrosis in the liver were observed in the group $\mathrm{C}$, as observed in the group $\mathrm{D}$, but in a more moderate degree to microvacuolar degeneration. Seric total protein, albumin, globulin and uric acid levels decreased in the group $\mathrm{C}$ and $\mathrm{D}$. The levels of alanine aminotransferase (ALT) increased in the group $\mathrm{C}$, and the treatment with adsorbent was able to avoid this increment. Seric and hepatic reactive oxygen species and TBARS increased in the group $\mathrm{C}$, and the treatment with adsorbent reduced theses parameters in the group D. Catalase (CAT) activity decreased, while ALA-D increased in the group C. The treatment with adsorbent was able to prevent CAT activity decrease, but it did not prevent the increase in ALA-D activity.

Discussion: Aflatoxins are considered one of the most important problems in poultry production causing high economic losses to producers. In this study, the use of adsorbent showed a protective effect to hepatic tissue, minimizing histopathological lesions, as well as by preventing lipid peroxidation and exacerbated production of free radicals. Based on this data, aflatoxin intoxication causes hepatic oxidative stress that contributes directly to disease pathogenesis, and the addition of an adsorbent containing $0.3 \%$ based on bentonite, yeast cell wall and silymarin may be considered a new approach to prevent cellular and hepatic damage caused by aflatoxins.

Keywords: mycotoxins, lipid peroxidation, free radicals, antioxidants, adsorbent. and Department of Biochemistry and Molecular Biology \& ${ }^{3}$ Department of Microbiology and Parasitology, Universidade Federal de Santa Maria (UFSM), Santa Maria, RS, Brazil. CORRESPONDENCE: A.S. Da Silva [aleksandro_ss@ yahoo.com.br - Tel.: +55 (49) 2049-9560]. Departamento de Zootecnia, Universidade do Estado de Santa Catarina (UDESC). Rua Beloni Trombeta Zanini n. 680E. Bairro Santo Antônio. CEP 89815-630 Chapecó, SC, Brazil. 


\section{INTRODUCTION}

Aflatoxins are mycotoxins produced by fungi belonging to the genus Aspergillus flavus and Aspergillus parasiticus found mainly in grains used for animal nutrition. When present at levels greater than the maximum allowed they may cause serious damage to the animals $[8,17]$, since they are rapidly absorbed in the gastrointestinal tract, causing significant damage in the hepatic tissue [11]. Aflatoxins intake by birds can cause toxic effects directly or indirectly, which depends on the concentration, time of exposure, and the type of the aflatoxin [24]. Intoxication by aflatoxin leads to weight loss and lower food intake [9], and also affects seric parameters such as total protein, albumin, glucose, cholesterol, uric acid, and creatinine [16]. Many authors reported microscopic alterations in the cardiac and hepatic tissue, such as vacuolar degeneration $[7,14,26]$, affecting directly animal performance [30]. The use of adsorbents in the feed minimize the toxic effects caused by aflatoxins [13,17,27].

The hepatic tissue is responsible for metabolize and store nutrients, such as proteins, carbohydrates and lipids. Intoxication by aflatoxins can cause oxidative stress, characterized by disturbance in the antioxidant/ oxidant status, resulting in oxidative damage due to the biomolecular damage caused by the attack of free radicals or reactive oxygen species (ROS) and consequently inhibition of antioxidant enzymes [1,21]. The aim of this study was to evaluate whether the use of an adsorbent prevents or reduces the oxidative stress in quails (Coturnix coturnix) fed with aflatoxin-contaminated diet.

\section{MATERIALS AND METHODS}

\section{Aflatoxins}

Aflatoxins were produced by fermentation in converted rice under constant stirring and controlled temperature. The NRLL 2999 strain of Aspergillus parasiticus was used according to the method described by West et al. [35]. After autoclaving with open valve, the rice was dried with hot air and grounded in a laboratory mill. The aflatoxin concentration was determined by the HPLC method [34]. After fermentation, a total of 130 $\mathrm{mg}$ of aflatoxins $/ \mathrm{kg}$ of rice was obtained, containing approximately $83 \%$ of aflatoxin $\mathrm{B} 1,9.5 \%$ of aflatoxin B2, 3.4\% of aflatoxin $\mathrm{G} 1$, and $4.2 \%$ of aflatoxin $\mathrm{G} 2$. Grounded rice was added to the feed as required, never exceeding $1 \%$ of the total diet.
Animals

Quails used in this study were originated from eggs of Coturnix coturnix japonica incubated during 17 days under appropriate conditions up to hatch. During the initial period ( 1 to 25 days of age), the quails were maintained on wood shaving litter with food and water ad libitum. At 26 days of age, the quails were transferred to metabolic cages with nipple drinkers and galvanized feeders under controlled temperature $\left(37^{\circ} \mathrm{C}\right)$ in the first week, and $3^{\circ} \mathrm{C}$ weekly decrease up to room temperature at $24-27^{\circ} \mathrm{C}$. At 75 days of age, 28 quails were allocated in four cages according to the experimental design described below.

\section{Experimental design}

Twenty-eight quails were divided in a completely randomized design composed by four groups with seven animals each. Animal feed was composed of corn and soybean meal, according to the nutritional requirements for quails [29]. The same feed was used in all groups, changing only the treatments. The group A was composed by quails that received the diet without aluminosilicate adsorbent (the control group); the group B was composed by quails that received the diet supplemented with adsorbent containing aluminosilicates; the group $\mathrm{C}$ was composed by quails that received diet contaminated with aflatoxins (200 $\mathrm{ppb}$ ); and the group D was composed by quails that received diet contaminated with aflatoxins (200 ppb) and treated with adsorbent containing aluminosilicates. The composition adsorbent containing $0.3 \%$ based on bentonite, yeast cell wall and silymarin. The animals received feed and water ad libitum during 20 days.

Sample collection

On day 20, the quails were euthanized by cervical dislocation. Total blood was collected by cardiac puncture in tubes without anticoagulant to obtain serum (centrifuged at $3500 \mathrm{~g}$ during $10 \mathrm{~min}$ ) for later determination of biochemical parameters. The liver was placed in a solution of Tris- $\mathrm{HCl} 10 \mathrm{mM}, \mathrm{pH} 7.4$ for TBARS, ROS, SOD and CAT analysis. The hepatic tissue was gently homogenized in a glass potter in specific buffer, homogenated, and centrifuged at $10.000 \mathrm{~g}$ at $4^{\circ} \mathrm{C}$ for $10 \mathrm{~min}$ to yield a supernatant (S1) used for analyses. Homogenate aliquots were stored at $-80^{\circ} \mathrm{C}$ until utilization. Fragments of liver and intestine $(5 \mathrm{~cm})$ were collected for histopathological analyses. 


\section{Biochemical analyses}

The serum was used to evaluate alanine aminotransferase (ALT), uric acid, total protein and albumin levels, while blood or serum and liver were used to evaluate oxidative stress parameters, such as TBARS, ROS, SOD, CAT and ALA-D.

\section{Serum biochemistry}

Seric ALT, uric acid, total protein, and albumin levels were evaluated in a semi-automated BioPlus $(2000)^{1}$ using commercial kits. Globulins were calculated based on the total of protein and albumin levels (globulin $=$ total protein - albumin $)$.

\section{Lipid peroxidation and free radicals}

Lipid peroxidation was estimated by measuring TBARS, and expressed in terms of malondialdehyde (MDA) content. In this method, MDA is a final product of fatty acid peroxidation that reacts with thiobarbituric acid (TBA) ${ }^{2}$ to form a colored complex. The TBARS was analyzed in serum according to Jentzsch et al. [15]. The tissue homogenates ( $200 \mu \mathrm{L}$ of S1) were incubated at $95^{\circ} \mathrm{C}$ for $60 \mathrm{~min}$ in acid medium containing $8.1 \%$ sodium dodecyl sulfate, $0.5 \mathrm{~mL}$ of acetic acid buffer (500 mM, pH 3.4) and 0.6\% TBA. TBARS levels were measured at $532 \mathrm{~nm}$, and the absorbance was compared with the standard curve using malondialdehyde according to the method of Ohkawa et al. [25]. The results were expressed in nmoles of malondialdehyde/ $\mathrm{mg}$ of protein.

ROS levels were measured using 2'-7'-Dichlorofluorescein (DCFH) as an index of the peroxide production by the cellular components [12]. The serum $(10 \mu \mathrm{L})$ and liver $(0.8 \mu \mathrm{g}$ of protein) were added to a medium containing Tris- $\mathrm{HCl}$ buffer (10 mM; pH 7.4) and DCFH-DA $(1 \mathrm{mM})$. The results were expressed by $\mathrm{U} D C F / m g$ protein.

\section{Antioxidant system}

Hepatic catalase (CAT) activity was determined by the decomposition of $\mathrm{H} 2 \mathrm{O} 2$ at $240 \mathrm{~nm}$ according to the method described by Nelson and Kiesow [23], and modified by Aebi [2]. Superoxide dismutase (SOD) activity in the liver was quantified spectrophotometrically at $480 \mathrm{~nm}$ according to Misra and Fridovich [20] by determining the inhibition of auto-oxidation of epinephrine to adrenochrome at an alkaline $\mathrm{pH}$. For the SOD assay, 10-40 $\mu \mathrm{g}$ of protein was used, whereas CAT activity was determined using $10-40 \mu$ g protein.
CAT and SOD results were expressed in nmol CAT/ $\mathrm{mg}$ of protein and UI SOD/mg protein, respectively. -ALA-D activity was assayed in the liver $(200 \mu \mathrm{L} ; 0.8$ $\mu \mathrm{g}$ of protein) by the method of Sassa [31], and results were expressed in $\mathrm{nmol} \mathrm{PBG} / \mathrm{h} / \mathrm{mg}$ of protein.

\section{Protein determination}

Protein content was determined by the Coomassie blue method according to Bradford [5] using bovine sera albumin as a standard. The protein supernatant $1(\mathrm{~S} 1)$ of tissue at $0.6-0.8 \mathrm{mg} / \mathrm{mL}$ of protein was kept until analysis.

\section{Histopathology}

Fragments of liver and intestines were fixed in buffered formalin $10 \%$ solution, routinely processed, and stained with hematoxylin and eosin technique (H\&E) for histopathological analyses.

\section{Statistical analysis}

The data were submitted to normality test (Shapiro), which showed normal distribution. Thus, the one-way analysis of variance (ANOVA) followed by the Tukey post hoc test was used to verify the difference between groups, considering $P<0.05$.

\section{RESULTS}

Between days 15 to 20 of the experiment, group $\mathrm{C}$ quails showed clinical signs, such as apathy, creepy feathers and reduced feed intake. Due to these changes, only in the quails of group $\mathrm{C}$, we chose day 20 to finalize the experiment.

Macroscopically, the liver of quails belonging to the group $\mathrm{C}$ showed greenish yellow color differently from the other groups. Microscopically, no alterations were observed in the liver of animals in groups A and B. Severe diffuse microvacuolar degeneration (hydropic) of hepatocytes and small foci of necrosis in the liver were observed in the group $\mathrm{C}$, as observed in the group $\mathrm{D}$, but in a more moderate degree to microvacuolar degeneration.

Seric levels of total protein, albumin, uric acid and globulins reduced in the group $\mathrm{C}$ and D compared to the control group (the group A). Animals intoxicated by aflatoxins (the group C) showed increased ALT levels compared to the control group (the group A). The treatment with adsorbents (the group D) reduced the ALT levels compared to intoxicated and untreated quails (the group C) [Table 1]. 
The TBARS and ROS levels in serum and hepatic tissue were increased in aflatoxin-intoxicated quails (the group C) compared to the control group (the group A). The treatment with the adsorbent prevented the increase in TBARS and ROS levels in serum and liver of aflatoxin-intoxicated quails (the group D) compared to intoxicated and untreated quails (the group C) [Table 2].

SOD, CAT and ALA-D activities in the hepatic tissue are shown in Table 2. Aflatoxin intoxication increase the hepatic SOD activity (groups $\mathrm{C}$ and
D. The hepatic CAT activity showed a significant decrease in intoxicated and untreated quails (the group C) compared to the control group (the group A). The treatment with adsorbent prevented the reduction on CAT activity in intoxicated animals treated with adsorbent (the group D) compared to intoxicated and untreated quails (the group C). The hepatic ALA-D activity increased in intoxicated and untreated quails (the group C) compared to control group (the group A). The treatment with adsorbent did not affect this enzyme.

Table 1. Seric levels of total protein, albumin, globulin, alanine aminotransferase (ALT) and uric acid of quails intoxicated by aflatoxins and treated with an aluminosilicate adsorbent.

\begin{tabular}{|c|c|c|c|c|c|}
\hline Variable & Group A & Group B & Group C & Group D & $P$ value \\
\hline Total protein $(\mathrm{g} / \mathrm{dL})$ & $4.1 \pm 0.9^{\mathrm{a}}$ & $3.8 \pm 0.2^{\mathrm{a}}$ & $2.7 \pm 0.4^{b}$ & $2.9 \pm 0.5^{\mathrm{b}}$ & $<0.001$ \\
\hline Albumin (g/dL) & $1.2 \pm 0.2^{\mathrm{a}}$ & $1.1 \pm 0.4^{\mathrm{a}}$ & $0.7 \pm 0.15^{\mathrm{b}}$ & $0.8 \pm 0.2^{b}$ & $<0.001$ \\
\hline Globulin (g/dL) & $2.9 \pm 0.7^{\mathrm{a}}$ & $2.7 \pm 0.3^{\mathrm{a}}$ & $2.0 \pm 0.2^{b}$ & $2.1 \pm 0.3^{b}$ & $<0.05$ \\
\hline ALT (U/L) & $5.5 \pm 1.6^{\mathrm{c}}$ & $9.5 \pm 3.3^{\mathrm{bc}}$ & $33.5 \pm 19.4^{\mathrm{a}}$ & $12.5 \pm 7.2^{b}$ & $<0.001$ \\
\hline Uric acid (mg/dL) & $6.3 \pm 1.4^{\mathrm{a}}$ & $7.7 \pm 2.2^{\mathrm{a}}$ & $3.2 \pm 2.0^{\mathrm{b}}$ & $4.0 \pm 2.3^{b}$ & $<0.001$ \\
\hline
\end{tabular}

Note: Means followed by the same letter in the same line do not differ significantly in the Tukey test $(P>0.05)$. Group A- control diet; Group B- control diet $+0.3 \%$ of the adsorbent; Group-C diet contaminated with $200 \mathrm{ppb}$ of aflatoxins; Group D- diet contaminated with $200 \mathrm{ppb}+0.3 \%$ of the adsorbent.

Table 2. Effects of aflatoxin on biomarkers of oxidative stress in blood/serum and liver of quails treated with an aluminosilicate adsorbent. Thiobarbituric acid-reactive substances (seric TBARS: $\mu \mathrm{mol} \mathrm{MDA} / \mathrm{mL}$; hepatic TBARS: $\mu$ mol MDA/mg protein), reactive oxygen species (ROS: U DCF /mg protein), catalase activity (CAT: nmol CAT/mg of protein), superoxide dismutase activity (SOD: UI SOD/mg protein) and delta-aminolevulinic acid dehydratase activity (ALA-D: nmol PBG/h/mg protein).

\begin{tabular}{cccccc}
\hline Variable & Group A & Group B & Group C & Group D & $P$ value \\
\hline TBARS in serum & $3.5 \pm 0.61^{\mathrm{bc}}$ & $3.0 \pm 0.62^{\mathrm{c}}$ & $6.4 \pm 1.15^{\mathrm{a}}$ & $3.9 \pm 0.68^{\mathrm{b}}$ & $<0.001$ \\
TBARS in liver & $4.4 \pm 1.10^{\mathrm{b}}$ & $4.9 \pm 0.71^{\mathrm{b}}$ & $8.7 \pm 2.31^{\mathrm{a}}$ & $3.1 \pm 0.43^{\mathrm{c}}$ & $<0.001$ \\
ROS in serum & $110.1 \pm 22.5^{\mathrm{b}}$ & $115.2 \pm 30.0^{\mathrm{b}}$ & $144.2 \pm 27.2^{\mathrm{a}}$ & $113.7 \pm 18.6^{\mathrm{b}}$ & $<0.05$ \\
ROS in liver & $1437.9 \pm 917^{\mathrm{b}}$ & $1385.7 \pm 481^{\mathrm{b}}$ & $2641.7 \pm 929^{\mathrm{a}}$ & $946.7 \pm 536^{\mathrm{b}}$ & $<0.05$ \\
SOD in liver & $4.8 \pm 1.0^{\mathrm{b}}$ & $4.2 \pm 0.8^{\mathrm{b}}$ & $7.8 \pm 2.5^{\mathrm{a}}$ & $9.6 \pm 2.0^{\mathrm{a}}$ & $<0.001$ \\
CAT in liver & $2.1 \pm 1.2^{\mathrm{b}}$ & $1.5 \pm 0.62^{\mathrm{b}}$ & $0.6 \pm 0.35^{\mathrm{c}}$ & $4.2 \pm 2.1^{\mathrm{a}}$ & $<0.001$ \\
ALA-D in liver & $0.85 \pm 0.42^{\mathrm{b}}$ & $1.0 \pm 0.37^{\mathrm{b}}$ & $1.71 \pm 0.2^{\mathrm{a}}$ & $1.67 \pm 0.6^{\mathrm{a}}$ & $<0.01$
\end{tabular}

Note: Means followed by the same letter in the same line do not differ significantly in the Tukey test $(P>0.05)$. Group A - control diet; group B - control diet $+0.3 \%$ of the adsorbent; group C: diet contaminated with $200 \mathrm{ppb}$ of aflatoxin; group D - diet contaminated with $200 \mathrm{ppb}+0.3 \%$ of the adsorbent. 


\section{DISCUSSION}

Aflatoxins are considered one of the most important problems in poultry production causing high economic losses to producers $[18,26]$ due to lower performance and clinical state of hypoproteinemia, hypoalbuminemia and hyperglobulinemia, as observed in this present study. Protein reduction and increase in ATL activity in aflatoxin-intoxicated quails are compatible with hepatic damage. However, the treatment with adsorbent was unable to reduce or prevent the negative effects on protein levels, but reduced the ALT activity. Thus, the adsorbent avoids, in part, the hepatic damage, as seen in the histopathological analysis, since intoxicated animals treated with adsorbent showed moderate hepatic lesions, differently from what was observed in intoxicated and untreated quails. The enzyme ALT is considered an important marker of acute hepatic damage, being involved in the metabolism of amino acids, and its seric increase is due to damage in cellular membranes of the hepatocytes [4]. The reduction in uric acid levels in intoxicated quails may be linked to reduced protein levels, since uric acid is the end product of protein metabolism in birds [11], such as observed in this study. It is important to emphasize that reductions on seric total protein and albumin levels also indicate hepatic damage during intoxications by aflatoxins [4]. Moreover, lower globulins may compromise the immunity of intoxicated quails, since they are important molecules involved in the development of immunity [22]. Therefore, aflatoxin intoxication causes hepatic damage in quails, and the use of adsorbent may be considered as an alternative to reduce hepatic lesions.

The consumption of aflatoxins by quails for 20 days induced lipid peroxidation and increased ROS levels in the serum and liver, as reported in rats [1]. The presence of aflatoxins in the diet alters the membrane fluidity, causing lipid damage to hepatocytes and, consequently, impairing protein synthesis [1]. It is important to emphasize that the treatment with adsorbent in the diet was able to prevent lipid peroxidation. The mechanism of action remains unknown, but evidences suggest that adsorbents are able to minimize or inhibit lipid oxidative reactions, and consequently, prevent lipid peroxidation. Also, these results can be linked to the mechanism of action of adsorbents, due to the fact that they prevent the uptake of aflatoxins by the gastrointestinal tract, i.e., reduced lipid peroxidation might be a consequence of a minor degree of intoxication. ROS is considered an important biomarker of protein oxidation, and excessive ROS levels may explain the reduction of seric protein levels [19]. In this sense, we suggest that increased oxidant levels can contribute to disease pathophysiology, and hepatic damage. The excessive ROS production is capable of producing superoxide and hydrogen peroxide, free radicals neutralized by antioxidant enzymes, such as CAT and SOD [28], that were altered during aflatoxin intoxication.

Cell damage is commonly observed due to excessive formation of free radicals, as evidenced in this study by increased ROS levels, or by the impairment in the antioxidant defense system [1]. As a consequence of the oxidative stress already mentioned in this study, CAT activity was reduced in intoxicated quails, as similarly observed by Althnaian [3] in rats intoxicated by aflatoxin B1. According to this author, the deficiency in CAT activity results in oxidative stress, contributing to disease pathogenesis, due to increased levels of free radical hydrogen peroxides. In addition, the same significative reduction in CAT activity has been reported in the liver of rats aflatoxin-fed [10].

In this study, the ALA-D activity increased in quails aflatoxin-intoxicated, an enzyme sensible to oxidants [32]. Thus, we believe that ALA-D activity increased due to its relation to oxidative stress, such as observed in this study. In addition, the alteration in the activity of ALA-D may interfere in hematopoiesis, since this enzyme participates in the synthesis of porphobilinogen, that catalysis two delta-aminolevulinate molecules, i.e., a precursor of heme group [6]. The hypothesis may corroborated to the hemolytic anemia observed during intoxication by aflatoxins, where a decreased in erythrocytes counts, hemoglobin content, leucopenia and bone marrow hyperplasia was evidenced [33]. Although the hematological parameters have not been evaluated, the ALA-D activity may increase as a compensatory mechanism in an attempt to avoid hematological injuries caused by the intoxication.

\section{CONCLUSION}

In this study, the use of adsorbent showed a protective effect to hepatic tissue, minimizing histopathological lesions, as well as by preventing lipid peroxidation and exacerbated production of free radicals. Based on this data, aflatoxin intoxication causes hepatic oxidative stress that contributes directly to disease pathogenesis, and the addition of an aluminosilicate adsorbent may be considered a new approach to prevent cellular and hepatic damage caused by aflatoxins. 
MANUFACTURERS

${ }^{1}$ Bioplus Produtos para Laboratórios Ltda. Barueri, SP, Brazil.

${ }^{2}$ Sigma-Aldrich Brasil. São Paulo, SP, Brazil.

Acknowledgments. The funding agency (CNPq) for the provision of grants research productivity to corresponding author. Thanks to the collaborators in a project stage: Lenilson F. Roza, Maria Rosa M. Schetinger, and Ricardo E. Mendes.
Ethical approval. This experiment was approved by the Ethics Committee on Animal Research of Universidade do Estado de Santa Catarina (UDESC), under protocol number CEUA 5437120216.

Declaration of interest. The authors report no conflicts of interest. The authors alone are responsible for the content and writing of the paper.

\section{REFERENCES}

1 Abel S. \& Gelderblom W.C.A. 1998. Oxidative damage and fumonisin B1-induced toxicity in primary rat hepatocytes and rat liver in vivo. Toxicology. 131(2): 121-131.

2 Aebi H. 1984. Catalase in vitro. Method Enzymology. 105(1): 121-126.

3 Althnaian T. 2016. Gene expression and activities of antioxidant enzymes in kidneys of rats intoxicated with aflatoxin B1. Journal of Biological Sciences. 16(1): 65-71.

4 Batina P.N., Lopes S.T.A. \& Santurio J.M. 2005. Efeitos da adição de montmorilonita sódica na dieta sobre o perfil bioquímico de frangos de corte intoxicados com aflatoxina. Ciência Rural. 35(6): 826-883.

5 Bradford M. 1976. A rapid and sensitive method for the quantification of microgram quantities of protein utilizing the principle of protein-dye binding. Analytical Biochemistry. 72(2): 248-254.

6 Brito V.B., Folmer V., Soares J.C., Silveira I.D. \& Rocha J.B. 2007. Long-term sucrose and glucose consumption decreases the delta-aminolevulinate dehydratase activity in mice. Nutrition. 23(6): 818-826.

7 Cardozo S.V., Cardozo T.S.F., Teixeira Filho W.L., Ferreira A.M.R. \& Lopes C.W.G. 2011. Alterações histopatológicas cardíacas em codornas japonesas (Coturnix japonica) intoxicadas experimentalmente com dose sub-letal de aflatoxina. Revista Brasileira de Medicina Veterinaria. 33(2): 210-214.

8 Chen J., Chen K., Yuan S., Peng X., Fang J., Wang F., Cui H., Chen Z., Yuan J. \& Geng Y. 2013. Effects of aflatoxin B1 on oxidative stress markers and apoptosis of spleens in broilers. Toxicology and Industrial Health. 2013(1): $1-7$.

9 Eraslan G., Liman B.C., Guclu B.K., Atasever A., Koc A.N. \& Beyaz L. 2004. Evaluation of aflatoxin toxicity in japanese quails given various doses of hydrated sodium calcium aluminosilicate. Bulletin of the Veterinary Institute in Pulawy. 48(5): 511-517.

10 El-Bahr S.M. 2015. Effect of curcumin on hepatic antioxidant enzymes activities and gene expressions in rats intoxicated with aflatoxin B1. Phytotherapy Research. 29(1): 134-140.

11 Franciscato C., Lopes S.T.A., Santurio J.M., Wolkmer P., Maciel R.M., Paula M.T., Garmatz B.C. \& Costa M.M. 2006. Concentrações séricas de minerais e funções hepática e renal de frangos intoxicados com aflatoxina e tratados com montmorilonita sódica. Pesquisa Agropecuária Brasileira. 41(8): 1573-1577.

12 Halliwell B. \& Gutteridge J.M.C. 2007. Free radicals in biology and medicine. 4th edn. New York: Oxford University Press, 851p.

13 Herzallah S.M. 2013. Aflatoxin b1 residues in eggs and flesh of laying hens fed aflatoxin b1 contaminated diet. American Journal of Agricultural and Biological Sciences. 8(1): 156-161.

14 Ibrahim Q.Q. 2013. Histopathological study of quails liver experimentally induced by aflatoxin. Brazilian Journal of Veterinary Research and Animal Science. 12(1): 116-127.

15 Jentzsch A.M., Bachmann H., Fürst P. \& Biesalski H.K. 1996. Improved analysis of malondialdehyde in human body fluids. Free Radical Biology \& Medicine. 20(2): 251- 256.

16 Kasmani F.B., Torshizi M.A.K. Allameh A. \& Shariatmadari F. 2012. A novel aflatoxin-binding Bacillus probiotic: Performance, serum biochemistry, and immunological parameters in Japanese quail. Poultry Science. 91(12): 18461853.

17 Ledoux D.R., Rottinghaus G.E., Bermudez A.J. \& Alonso-Debolt M. 1998. Efficacy of a hydrated sodium calcium aluminosilicate to ameliorate the toxic effects of aflatoxin in broiler chicks. Poultry Science. 77(2): 204-210.

18 Madheswaran R., Balachandran C. \& Manohar B.M. 2004. Influence of dietary culture material containing aflatoxin and T2 toxin on certain serum biochemical constituents in Japanese quail. Mycopathologia. 158(3): 337-341. 
19 Mary V.S., Theumer M.G., Arias S.L. \& Rubinstein H.R. 2012. Reactive oxygen species sources and biomolecular oxidative damage induced by aflatoxin B1 and fumonisin B1 in rat spleen mononuclear cells. Toxicology. 302(2): 299307.

20 Misra H.P. \& Fridovich I. 1972. The role of superoxide anion in the autoxidation of epinephrine and a simple assay for superoxide dismutase. Journal of Biological Chemistry. 247(12): 3170-3175.

21 1Muller F.L., Lustgarten M.S., Jang Y., Richardson A. \& Remmen H.V. 2007. Trends in oxidative aging theories. Free Radical Biology \& Medicine. 43(5): 477-503.

22 Nazar F.N., Magnoli A.P., Dalcero A.M. \& Marin R.H. 2012. Effect of feed contamination with aflatoxin B1 and administration of exogenous corticosterone on Japanese quail biochemical and immunological parameters. Poultry Science. 91(1): 47-54.

23 Nelson D.P. \& Kiesow L.A. 1972. Entalpy of the composition of hydrogen peroxide by catalase at $25^{\circ} \mathrm{C}$. Analytical Biochemistry. 49(4): 474-479.

24 Ogido R., Oliveira C.A.F., Ledoux D.R., Rottinghaus G.E., Corrêa B., Butkeraitis P., Reis T.A., Gonçales E. \& Albuquerque R. 2004. Effects of prolonged administration of aflatoxin B1 and fumonisin B1 in laying Japanese quail. Poultry Science. 83(10): 1953-1958

25 Ohkawa H., Ohishi N. \& Yagi K. 1978. Assay for lipid peroxides in animal tissues by thiobarbituric acid reaction. Analytical Biochemistry. 95(3): 351-358.

26 Oliveira C.A.F., Butkeraitis P., Rosmaninho J.F., Guerra J.L., Corrêa B. \& Reis T.A. 2004. Alterações hepáticas em codornas japonesas submetidas à intoxicação prolongada por aflatoxina B1. Ciência Rural. 34(2): 213-217.

27 Ramos A.J. \& Hernandez E. 1996. In situ absorption of aflatoxins in rat small intestine. Mycopathologia. 134(1): 27-30.

28 Rodrigues J.V. \& Gomes C.M. 2012. Mechanism of superoxide and hydrogen peroxide generation by human electrontransfer flavoprotein and pathological variants. Free Radical Biology and Medicine. 53(1): 12-19.

29 Rostagno H.S., Albino L.F.T., Donzele J.L., Gomes P.C., Oliveira R.F., Lopes D.C., Ferreira A.S., Barreto S.L.T. \& Euclides R.F. 2011. Tabelas brasileiras para aves e suínos: composição de alimentos e exigências nutricionais. Departamento de Zootecnia. Viçosa: UFV, 252 p.

30 Santurio J.M., Mallmann C.A., Rosa A.P., Appel G., Heer A., Dageförde S. \& Böttcher M. 1999. Effect of sodium bentonite on the performance and blood variables of broiler chickens intoxicated with aflatoxins. Bristh Poultry Science. 40(1): 115-119.

31 Sassa S. 1998. ALA-D porphyria. Seminars in Liver Disease. 18(1): 95-101.

32 Souza J.B., Rocha J.B., Nogueira C.W., Borges V.C., Kaizer R.R., Morsch V.M., Dressler V.L., Martins A.F., Flores E.M. \& Schetinger M.R. 2007. Delta-aminolevulinate dehydratase (delta ALA-D) activity in diabetes and hypothyroidism. Clinical Biochemistry. 40(2): 321-325.

33 Tessari E.N.C., Oliveira C.A.F., Cardoso A L.S.P., Ledoux D.R. \& Rottinghaus G.E. 2005. Efeitos da aflatoxina B1 e fumonisina B1 sobre os níveis séricos de aspartato amino-transferase e proteína total de frangos de corte. Arquivos do Instituto Biológico. 72(1): 185-189.

34 Thorpe C.W., Ware G.M. \& Pohland A.E. 1982. Determination of aflatoxins by HPLC with a fluorescence detector and using postcolumn derivatization. In: Proceedings of the Fifth International IUPAC Symposium on Mycotoxins and Phycotoxins (Vienna, Austria). pp.52-55.

35 West S., Wyatt R. D. \& Hamilton P.B. 1973. Improved Yield of Aflatoxin by Incremental Increases of Temperature. Applied and Environmental Microbiology. 25(10): 1018-1019. 